\title{
Medical and humanitarian relief post-2004 Indian Ocean tsunami
}

\author{
Jeffrey Law (Meds 2016), Kyle Pangka (Meds 2016) \\ Faculty Reviewer: Dr Kanna Narayanan, MD (Department of Anesthesiology and Emergency Medicine)
}

\section{BACKGROUND OF TSUNAMI}

On the morning of December 26, 2004, an earthquake shook the west coast of Sumatra, causing a tsunami that inundated coastal communities with waves up to 30 meters high. Indonesia was the hardest-hit country, followed by Sri Lanka, India and Thailand. It was one of the deadliest natural disasters in recorded history; with a magnitude of 9.1, the earthquake was the third largest ever recorded on a seismograph. The earthquake caused the entire planet to vibrate as much as one centimetre and triggered other earthquakes as far away as Alaska. ${ }^{1}$

The tsunami killed over 275000 people in 14 countries, left tens of thousands of people injured and rendered over 10 million people homeless and displaced. Measured in casualties, this was the single deadliest tsunami in recorded history. ${ }^{2}$ Children accounted for more than a third of those killed because "they weren't strong enough to hold on to fixtures or trees to resist the surging tidal waves" 3 and up to 4 times more women than men perished in some regions because they were waiting on beaches for fishermen to return. ${ }^{4}$ In addition, up to 9000 foreign tourists staying in seaside resorts during the holiday travel season were among the dead or missing. ${ }^{5}$

\section{DAMAGE OF TSUNAMI TO HEALTH CARE SERVICES}

At a time where thousands of patients desperately needed medical attention, many of the health care sectors in the affected countries were too badly crippled to adequately meet the demand. For example, the tsunami destroyed 53 of the 244 health clinics in Indonesia, the country closest to the epicenter. In a country already low in numbers of doctors and nurses, it was estimated that as many as 691 health personnel were either confirmed dead or missing. ${ }^{6}$ Also disrupted were telephone lines, transportation, clean water supply and electricity, ${ }^{6}$ constituting a major blow to the health care system. In the Maldives, where $80 \%$ of the land is less than one meter above sea level, ${ }^{7}$ many clinics and hospitals were flooded and lost their medical records and equipment. ${ }^{8}$ Moreover, the island health care system depended heavily on expatriate physicians and nurses, many of whom left to go back to their native countries to be with family. ${ }^{8}$ In Sri Lanka, many of the patients who required orthopedic surgery had to be transferred to the inland capital of Colombo not only because the seaside hospitals were in poor condition that made large procedures risky to perform, but also because hospitals ran out of equipment. ${ }^{9}$

\section{RELIEF EFFORTS}

\section{A. LOCAL (INTERNAL) COOPERATION}

One of the efforts that received most praise was the coordination of relief that occurred within each of the affected nations. ${ }^{6}$ For example, one of the more complex challenges that arose immediately after the storm was the handling of the large number of dead bodies. In Indonesia alone, reports indicated that there were over 100000 dead bodies spread over the coastal sea line, which rapidly overwhelmed mortuary space. ${ }^{6}$ Efforts were further complicated in some cases by "pressures from the media and families of tourists who arrived seeking some type of closure on their relatives."10 Consequently, teams of health care personnel, police, military, relief workers and volunteers worked quickly and closely to dig out and handle large numbers of dead bodies in makeshift graves. ${ }^{8}$

Moreover, in response to the initial wave of patients, some countries were able to manage the influx by transferring them to hospitals in unaffected regions. For example, hospitals in the Maldives were able to coordinate and provide patient evacuations through a ferry and air charter system. ${ }^{10}$ Thailand also had pre-existing disaster management plans and was able to quickly provide emergency food, water and medical supplies to the worst-affected areas. ${ }^{11}$

While experiences of individuals left homeless by the storm varied between and within areas, reports indicate that in Sri Lanka, for example, friends and families were largely receptive to those affected, while schools and other public buildings in the Maldives were opened to accommodate large numbers of people left homeless. ${ }^{8}$

\section{B. FOREIGN (EXTERNAL) COOPERATION BETWEEN GOVERNMENTAL GROUPS, NON-GOVERNMENTAL ORGANIZATIONS AND MILITARY FORCES}

The scale of the tsunami was matched by an outpouring of material assistance. In total, US \$14 billion dollars in aid was pledged. ${ }^{2}$ Monetary aid aside, much of the relief was due to the rapid arrival of external emergency medical assistance. In total, the humanitarian relief effort brought together over 130 governmental and non-governmental (NGO) organizations from all over the world within the first 2 weeks that helped to deploy emergency health care staff. ${ }^{10}$

One of the greatest fears of the relief efforts was the possibility of epidemics due to the high population density and tropical climate of the affected areas. ${ }^{2}$ Fortunately, these problems were minimized due to the quick provision of fresh drinking water and sanitation facilities. The drinking water response was described as "timely, effective and comprehensive" and involved the combined efforts of United Nations agencies, NGOs, defense forces, private companies and individual volunteers. ${ }^{12}$

Military efforts also provided indispensable relief. In Indonesia, foreign militaries worked alongside national militaries and civilian relief teams to reach people in outlying areas that had been cut off. ${ }^{8}$ In the Maldives, the military provided supplies and constructed temporary shelters. ${ }^{8}$ In many cases, there was cooperation between relief units of foreign militaries and other international organizations to provide initial aid and assist in reconstruction efforts. ${ }^{13}$ 


\section{CANADA'S ROLE IN RELIEF EFFORTS}

\section{Canadian International Development Agency}

The Canadian International Development Agency (CIDA) was founded in 1968 to facilitate aid to developing countries.14 In 2004 it played a key role in coordinating and administering the financial aid from the Canadian government and Canadian public in areas affected by the tsunami: $\$ 425$ million of support was given by the Canadian Government and $\$ 230$ million was raised by the Canadian public.15 CIDA also coordinated humanitarian efforts through working with Foreign Affairs Canada, Canadian Public Health Agency, United Nations, the Red Cross, Oxfam and other major aid agencies.15 In 2013, CIDA merged with the Department of Foreign and International Affairs to become the Department of Foreign Affairs, Trade and Development (DFATD).14

\section{The Canadian Red Cross}

The Canadian Red Cross is a charity organization that engages in humanitarian projects and disaster response worldwide. Its workers provided aid to Indonesia, Sri Lanka, India and the Maldives using different types of emergency response units: $:^{16,17}$

\section{- Basic Health Care Unit}

- Responsible for outpatient clinic services, maternal-child health and uncomplicated deliveries and immunization and nutritional surveillance

- Involves local health care workers, expatriate doctors and nurses and interpreters

\section{- Referral Hospital}

- Functions as a first-level field hospital and can provide care for up to 250000 people

- Provides specialist services such as traumatology, obstetrics and pediatrics

\section{- Rapid Deployment Hospital}

- Can be established within 48 hours

- Focuses on triage, first aid, limited medical or surgical care and medical transport

Other emergency response units used by the Red Cross are involved in logistics, communications, water provision and sanitation efforts. ${ }^{17}$

It should be noted that the Canadian Red Cross in Sri Lanka also made an effort to provide psychosocial support for traumatized communities. ${ }^{18}$ Following the disaster, the Canadian Red Cross based in Sri Lanka launched training for 49 community health workers in psychosocial assistance. ${ }^{18}$ Their aim was to lessen the impact or onset of depression, insomnia and alcohol abuse and to prevent suicide. ${ }^{18}$

\section{Disaster Assistance Response Team}

The disaster assistance response team (DART) is made up of 200 Canadian Forces personnel. The purpose of DART is to provide emergency relief until international aid agencies are able to provide long-term support. ${ }^{19,20}$ The DART medical platoon treats minor injuries, leads preventative medicine initiatives and provides limited obstetrics; meanwhile, the engineering troop repairs roads and electrical systems, constructs temporary housing and operates water supply systems. ${ }^{19}$ The remaining members of DART assist in water sanitation, communication and security efforts. ${ }^{19}$ On January 2, 2005 Prime Minister Paul Martin announced that DART would be deployed to Sri Lanka. ${ }^{19,20}$ During their mission in Sri Lanka, DART was able to treat more than 7620 people and produce approximately 3.5 million litres of drinking water. ${ }^{19}$

\section{CHALLENGES RELATED TO COOPERATIVE RELIEF EFFORTS}

Because the 2004 Indian Ocean tsunami was such a large-scale disaster that drew such substantial numbers of relief agencies, the coordination of humanitarian operations posed many challenges. ${ }^{10}$ Many local ministries of health lacked suitable staff to coordinate the arrival and work of so many people, equipment and donations. ${ }^{10}$ Separately, some of the foreign aid groups were also reluctant to "coordinate their approaches among themselves or with local staff" and were also "not familiar with the cultures involved, did not speak the languages of the people [...] and were insensitive to the ways in which people in different societies respond to crisis., ${ }^{, 10}$ Agencies may have also been competing for funds and visibility which also limited their eagerness to coordinate. ${ }^{10}$

There were other cases where lack of communication and coordination contributed to resources being either duplicated or directly wasted. In one case, relief workers were sent to areas where help was not needed: "one wealthy foreign nation dispatched a team of 10 professionals to Thailand, but they were told there was nothing for them to do."11 There were also reports of inappropriate drugs donated, including drugs that were not relevant to the emergency situation or drugs that were already expired. In fact, approximately 150 metric tons of unusable medications were destroyed in Colombo alone, the capital city of Sri Lanka. ${ }^{22}$

\section{CONCLUSION}

The 2004 tsunami resulted in an immeasurable loss that challenged the health care systems in Indonesia, Sri Lanka, India and Thailand and pushed the international community to provide relief. Local and foreign health care workers came together to adjust to the high volume of injuries and displaced individuals. Sanitation and preventive medicine were critical in preventing epidemics and further loss of life.

Through reflecting on the events of the 2004 tsunami one can distill valuable insights. Following a crisis, coordination is paramount to ensure resources are used to their fullest potential. Furthermore, nonmedical professionals such as administrators, media personnel, engineers, translators, military troops and grief counsellors each have a significant role to play in relief efforts. Continuous teamwork in the aftermath of the 2004 tsunami smoothened the transition of affected countries from emergency measures into long-term recovery efforts. 


\section{REFERENCES}

1. West M, Sanches JJ, McNutt SR. Periodically triggered seismicity at Mount Wrangell, Alaska, after the Sumatra earthquake. Science. 2005 May;308(5725):1144-6.

2. National Geographic News. The deadliest tsunami in history? [Internet]. Washington, D.C.: National Geographic News; 2005 Jan 7 [cited 2014 Apr 5]. Available from: http://news.nationalgeographic.com/ news/2004/12/1227_041226_tsunami.html

3. Unicef. Children account for one third of tsunami dead [Internet]. New York: Unicef; 2004 Dec 28 [cited 2014 Apr 5]. Available from: http:// www.unicef.org/emerg/disasterinasia/index_24659.html

4. BBC News. Most tsunami dead female - Oxfam [Internet]. London: BBC News; 2005 Mar 26 [cited 2014 Apr 5]. Available from: http://news.bbc. co.uk/2/hi/asia-pacific/4383573.stm

5. Becken S, Hay JE. Tourism and climate change: risks and opportunities. Bristol: Channel View Publications; 2007. 63 p.

6. World Health Organization. Health aspects of the tsunami disaster in Indonesia December 26th 2004 [Internet]. Phuket: World Health Organization; 2005 May 4-6 [cited 2014 Apr 5]. Available from: http://www. who.int/hac/events/tsunamiconf/presentations/1_2_national_perspectives_indonesia_idrus_ppt.pdf

7. Maldives Disaster Knowledge Network [Internet]. Maldives: Maldives Disaster Knowledge Network; c2009. Hazard profile; c2009 [cited 2014 Apr 5]. Available from: http://www.saarc-sadkn.org/countries/maldives/hazard_profile.aspx

8. International Centre for Migration and Health. Interim report of a meeting on public health impact of the tsunami [Internet]. Geneva: International Centre for Migration and Health; 2005 Apr 22-24 [cited 2014 Apr 5]. Available from: www.alnap.org/pool/files/ICMH_Tsunami_Public_Health_Response.pdf

9. Calder J. Orthopaedics in Sri Lanka post-tsunami. J Bone Joint Surg Br. 2005 Jun;87(6):759-61.

10. Carballo M, Daita S, Hernandez M. Impact of the tsunami on health care system. J R Soc Med. 2005 Sep;98(9):390-5.

11. Watts J. Thailand shows the world it can cope alone. Lancet. 2005 Jan;365(9456):284

12. Classen T, Smith L, Albert J, Bastable A, Fesselet JF. The drinking water response to the Indian Ocean tsunami, including the role of household water treatment. Disaster Prev Manag. 2006; 15(1):190-201

13. Indian Ocean Tsunami and International Cooperation. Indian Ocean tsunami and international cooperation [Internet]. Japan: National Institute for Defense Studies; 2006 [cited 2014 Apr 7]. Available from: http://www.nids.go.jp/english/publication/east-asian/pdf/2006/eastasian_e2006_02.pdf

14. Government of Canada. Foreign Affairs Trade and Development: mission and mandate [Internet]. Ottawa: Government of Canada; 2013 Jun 19 [cited 2014 Mar 30]. Available from: http://www.acdi-cida.gc.ca/ acdi-cida/acdi-cida.nsf/eng/NIC-5493749-HZK.

15. Office of the Inspector General. Lessons from the tsunami: review of the response of foreign affairs Canada [Internet]. Ottawa: Foreign Affairs and International Trade Canada; 2005 May [cited 2014 Apr 5]. Available from: http://www.international.gc.ca/about-a_propos/oig-big/2005/ evaluation/tsunami.aspx?lang=eng.

16. Canadian Red Cross. Emergency response unit [Internet]. Ottawa: Canadian Red Cross; c1999-2014 [cited 2014 Mar 30]. Available from: http:// www.redcross.ca/what-we-do/emergencies-and-disasters-worldwide/ responding-to-international-emergencies/emergency-response-unit.

17. International Federation of Red Cross and Red Crescent Societies. Emergency response unit types [Internet]. Geneva: International Federation of Red Cross and Red Crescent Societies; [cited 2014 Mar 30].
Available from: http://www.ifrc.org/en/what-we-do/disaster-management/responding/disaster-response-system/dr-tools-and-systems/eru/ types-of-eru/.

18. Davie P. Canadian Red Cross joins efforts to rebuild hospitals destroyed by the tsunami in Sri Lanka [Internet]. Ottawa: Canadian Red Cross; c1999-2014 [cited 2014 Mar 30]. Available from: http://www.redcross. ca/donate/your-donation-in-action/past-appeals/international/2004/ asia-earthquake-and-tsunamis-relief/canadian-red-cross-joins-effortsto-rebuild-hospitals-destroyed-by-the-tsunami-in-sri-lanka.

19. National Defence and the Canadian Armed Forces. The Disaster Assistance Response Team [Internet]. Ottawa: Government of Canada; 2013 Nov 14 [cited 2014 Mar 30]. Available from: http://www.forces.gc.ca/en/ operations-abroad-recurring/dart.page

20. CBC News. Disaster relief: Canada's rapid response team [Internet]. Toronto: CBC news; 2011 Mar 14 [cited 2014 Mar 30]. Available from: http://www.cbc.ca/news/canada/disaster-relief-canada-s-rapid-response-team-1.866930.

21. WHO Regional Office for South-East Asia. The tsunami and after: emergency doctor says WHO has key role in health crises [Internet]. Geneva: World Health Organization; 2005 Feb1 [cited 2014 Mar 30]. Available from: http://www.who.int/bulletin/volumes/83/2/interview0205/en/ print.html

22. Hechmann R, Bunde-Birouste A. Drug donations in emergencies, the Sri Lankan post-tsunami experience [Internet]. J humanitarian assistance; 2007 Sep 26 [cited 2014 Apr 7]. Available from: https://sites.tufts.edu/ $\mathrm{jha} / \operatorname{archives} / 54$. 